\title{
O ltamaraty e a Política Externa Brasilleira: Do Insulamento à Busca de Coordenação dos Atores Governamentais e de Cooperação com os Agentes Societárïos*1
}

\section{Carlos Aurélio Pimenta de Faria**}

A despeito da histórica e amplamente reconhecida centralidade do Ministério das Relações Exteriores (MRE), ou quase monopólio, segundo os seus muitos críticos, na produção da política externa brasileira, apenas recentemente o órgão, também conhecido como Itamaraty, passou a ocupar lugar de mais destaque na agenda de pesquisa dos analistas acadêmicos da inserção internacional do país. Hoje, os trabalhos pioneiros de Barros (1986) e Cheibub (1985, 1989), que

\footnotetext{
* Artigo recebido em 23 de maio de 2011 e aprovado para publicação em 17 de agosto de 2011. ** Doutor em Ciência Política pelo Instituto Universitário de Pesquisas do Rio de Janeiro (Iuperj) e professor dos Programas de Pós-graduação em Relações Internacionais e em Ciências Sociais da Pontifícia Universidade Católica de Minas Gerais (PUC-Minas). E-mail: carlosf@ pucminas.br.
}

CONTEXTO INTERNACIONAL Rio de Janeiro, vol. 34, noำ 1, janeiro/junho 2012, p. 311-355. 
enfocaram as estruturas e dinâmicas organizacionais do MRE, bem como o seu peculiar ethos corporativo, têm sido retomados e atualizados por uma diversidade de autores, como, por exemplo: Faria (2008), Farias (2009), Figueira (2010), Lima (2010), Lopes et al. (2010), Lopes (2010), Moura (2006, 2007), Nogueira et al. (2009), Pinheiro (2009), Pinheiro et al. (2007), Puntigliano (2008), Silva et al. (2010) e Vigevani e Mariano (1997).

Até meados da década de 1990, prevalecia entre os analistas, bem como entre diversos stakeholders da sociedade civil, a percepção do Itamaraty, agência estatal responsável pela implementação da política exterior do país, mas que frequentemente tem assumido também, nas últimas décadas, o encargo de formulação dessa política, como instituição fortemente insulada, pouco transparente e pouco responsiva às demandas e aos interesses dos demais atores políticos, burocráticos e societários.

Não obstante esta percepção até há pouco hegemônica, diversas das análises mais recentes têm argumentado que se estão avolumando no país as pressões no sentido da conformação de um processo de produção da política externa que seja mais poroso, plural ou democrático. Fatores de diversas ordens, no plano doméstico e relativos ao sistema internacional, têm convergido nesse sentido.

A maior atenção devotada hoje ao papel do Itamaraty parece ser o resultado não apenas da crescente politização da política externa do país, mas também da própria expansão e da consolidação do campo das Relações Internacionais (RI) no Brasil. Note-se, contudo, que, a despeito dessa expansão do campo, com a criação de dezenas de cursos de graduação em RI, bem como de um número já significativo de programas de pós-graduação, parece correto afirmarmos que a subárea da Análise da Política Externa ainda padece, no país, de um grau de institucionalização talvez aquém do desejado. Basta recordarmos que, no âmbito da graduação, é relativamente rara a oferta de cursos 
específicos, distintos da tradicional disciplina "política externa brasileira" (ou "história da política externa brasileira"). Havia, em 2011, 102 graduações em RI registradas no Ministério da Educação, a grande maioria em instituições de ensino privadas. Dessas 102, tivemos acesso às grades curriculares de 87 cursos, nos quais são ofertadas 172 disciplinas dedicadas à política externa, entre obrigatórias, a esmagadora maioria, e optativas. ${ }^{2}$ Incluem-se, aí, aquelas com um enfoque mais histórico, bem como aquelas que privilegiam a diplomacia. Dessas 172, apenas quinze (ou 24, se incluirmos as nove disciplinas de "introdução à política exterior") parecem se filiar com mais clareza à subárea da Análise de Política Externa, assumidamente interdisciplinar, que tem por objetivo principal apreciar a maneira como o posicionamento internacional dos Estados é produzido a partir de complexas interações entre atores e instituições do plano doméstico, estatais e não estatais, levando-se em consideração a sua percepção acerca dos constrangimentos e oportunidades advindos do sistema internacional.

No que diz respeito à pós-graduação, o panorama parece não ser muito diferente, mesmo que, também aqui, o espaço destinado à política externa seja significativo. Dos onze programas de pós-graduação em RI reconhecidos pela Coordenação de Aperfeiçoamento de Pessoal de Nível Superior (CAPES) (dados de meados de 2011), apenas três são ofertados por instituições privadas, havendo somente três que ofertam o Doutorado. Sete desses onze programas têm linhas de pesquisa dedicadas à política externa. Nestes programas, é ofertado um total de 26 disciplinas da área da política exterior, apenas seis delas obrigatórias (somente um dos onze programas não oferta disciplina alguma na área). Dentre essas 26 disciplinas, contudo, apenas três são denominadas "Análise de Política Externa"; e somente outras três têm conteúdo que pode ser pensado como equivalente. ${ }^{3}$

Este panorama parece dar sentido à afirmação de Paulo Roberto de Almeida (1999, p. 119) acerca do campo das RI no país, onde seria 
possível notar "uma certa ditadura benigna da história das relações internacionais sobre as demais disciplinas das ciências humanas (sociologia ou ciência política), bem como sobre as ciências sociais aplicadas (direito, administração ou economia)". Quando se percebe que, ainda hoje, a subárea da Análise de Política Externa tende a ser pouco privilegiada até nas grades curriculares dos cursos de pós-graduação em Relações Internacionais do país, torna-se legítimo pensarmos que o diagnóstico feito por Almeida há mais de uma década ainda pode ser visto como atual.

Reconhecendo que são crescentes as pressões no sentido da reversão do paradigma ainda relativamente insulado de produção da política exterior do Brasil, bem como a sua ampla repercussão doméstica hoje, este trabalho busca: (a) analisar os fatores, tanto domésticos como internacionais, que, a partir da redemocratização do país e das mudanças sistêmicas provocadas pelo fim da Guerra Fria, têm pressionado o Itamaraty no sentido da superação de seu insulamento; e (b) avaliar os instrumentos que têm sido empregados pelo MRE para a promoção da coordenação intragovernamental (no interior do Executivo) e intergovernamental (entre o Executivo federal e os governos subnacionais), bem como da cooperação intersetorial (governo federal e atores societários), na produção da política externa do país.

Para tanto, o trabalho está organizado da seguinte maneira: na primeira seção, partindo de uma breve discussão acerca das razões e lógicas do insulamento de determinados segmentos das burocracias estatais na produção das políticas públicas, são apresentados os fatores (políticos, burocráticos ou intragovernamentais, societários e relativos ao sistema internacional) que têm pressionado o MRE no sentido da adoção de uma postura menos insulada. A segunda seção discute alguns dos mecanismos colocados em prática pelo Itamaraty, no plano intragovernamental, para a promoção da ação concertada dos atores e agências estatais. A terceira é dedicada à apreciação da busca de cooperação, por parte do Itamaraty, com os governos subnacionais 
(cooperação intergovernamental). A quarta seção discute os esforços, empreendidos pelo MRE, de cooperação intersetorial, ou seja, com os atores do mercado e da sociedade civil, sendo aqui destacada a recente ênfase dada pela corporação diplomática brasileira à chamada diplomacia pública. As considerações finais questionam a suposta incapacidade de coordenação da política exterior por parte do Itamaraty. Argumenta-se que os esforços feitos pelo Itamaraty no sentido da superação do padrão insular de produção da política externa brasileira devem ser compreendidos como decorrência tanto das pressões extracorporativas, oriundas tanto do próprio governo federal como do universo político-partidário, dos governos subnacionais e dos agentes societários, quanto das clivagens internas ao próprio MRE, profundamente acentuadas durante o governo Lula da Silva.

\section{O Insulamento do Itamaraty sob Pressão}

Em seu estudo acerca da "gramática política do Brasil”, hoje referencial, Edson Nunes apresenta uma definição de "insulamento burocrático" que nos será útil. De acordo com o autor:

$\mathrm{Na}$ linguagem da teoria organizacional contemporânea, o insulamento burocrático é o processo de proteção do núcleo técnico do Estado contra a interferência oriunda do público ou de outras organizações intermediárias. Ao núcleo técnico é atribuída a realização de objetivos específicos. O insulamento burocrático significa a redução do escopo da arena em que interesses e demandas populares podem desempenhar um papel. Esta redução da arena é efetivada pela retirada de organizações cruciais do conjunto da burocracia tradicional e do espaço político governado pelo Congresso e pelos partidos políticos, resguardando estas organizações contra tradicionais demandas buro- 
cráticas ou redistributivas (NUNES, 1997, p. 34).

O Itamaraty passa a ser, após o final da Segunda Guerra Mundial, uma agência estatal progressivamente insulada, ${ }^{4}$ sob a guarda de uma corporação profissional altamente especializada, que até recentemente praticamente monopolizava, no país, a expertise nos assuntos internacionais, gozando de grande prestígio no interior da máquina pública, na sociedade de uma maneira geral e também no exterior, como ressaltado por uma diversidade de autores externos à corporação. Segundo Loureiro e Abrucio (1999, p. 79), seria possível afirmar que, no Estado brasileiro, o provimento dos cargos de alto escalão é bastante permeável à nomeação política, em função das características do sistema presidencialista do país e da ausência de carreiras estruturadas. Os autores, ao distribuir em um continuum o conjunto dos ministérios existentes, de acordo com o seu grau de abertura à nomeação política, pensada como distinta da nomeação burocrática, colocam os ministérios militares (antes da criação do Ministério da Defesa, em 1999) como "mais fechados", seguidos do Itamaraty, vindo depois o Ministério da Fazenda e, no polo dos "mais abertos", os demais ministérios.

Este continuum reitera o caráter "fechado" ou insular do Itamaraty. Nesse quesito, no âmbito da burocracia federal brasileira, apenas os antigos ministérios militares seriam mais fechados que o MRE à nomeação política para o provimento dos cargos de alto escalão. De fato, a carreira diplomática no Brasil é fortemente estruturada, tendo se institucionalizado em paralelo à progressiva profissionalização do corpo diplomático do país (CHEIBUB, 1985, 1989). Poucos cargos do serviço exterior brasileiro podem ser ocupados por pessoas de fora da carreira. De acordo com Figueira (2010, p. 9), o Itamaraty é o ministério "que menos comporta cargos comissionados e profissionais externos dentro de seu quadro funcional". Contudo, como é bem sabido, cabe ao presidente da República a escolha do ministro das Relações Exteriores. 
O Itamaraty e a Política Externa Brasileira: Do Insulamento à Busca de Coordenação...

Desde a instauração do regime militar no país, em abril de 1964, o Brasil teve quatorze distintos ministros das Relações Exteriores, sendo que metade deles não pertencia à carreira diplomática. ${ }^{5}$ Desses ministros não pertencentes à carreira, cujo grau de proximidade com a corporação diplomática foi variável, dois ocuparam o posto durante o regime militar e cinco durante a Nova República. As razões desta aparente maior confiança dos militares nos diplomatas foram explicadas de maneira convincente, ainda que incompleta, como veremos nas considerações finais deste trabalho, por Barros (1986). No entanto, quando se verifica o tempo de permanência no cargo dos ministros diplomatas, em contraste com o efetivo exercício do mandato por parte daqueles não pertencentes à carreira, observa-se que os diplomatas de carreira comandaram o MRE por mais que o dobro do tempo. Os não diplomatas foram ministros por aproximadamente 167 meses, apenas $29,50 \%$ do tempo total de 566 meses. ${ }^{6}$ Verifica-se, assim, o amplo predomínio dos diplomatas de carreira na gestão do Ministério.

Na verdade, a despeito do já tradicional "loteamento" dos ministérios, para a satisfação das bases partidárias dos presidentes da República, nisto que a ciência política do país convencionou denominar como o nosso "presidencialismo de coalizão", não parece haver evidências claras de que o cargo de ministro das Relações Exteriores seja fortemente cobiçado pelos partidos políticos. Nesse sentido, uma apreciação, mesmo panorâmica, do Orçamento Geral da União parece-nos reveladora. Dos mais de R $\$ 1,8$ trilhão autorizados para o Orçamento da União no ano de 2010 (ou exatos $\mathrm{R} \$ 1.848 .199 .882 .506,00$ ), apenas $0,12 \%$ (ou $\mathrm{R} \$ 2.215 .495 .031,00$ ) estava alocado na rubrica "Relações Exteriores". Das 29 funções ou rubricas especificadas, a apenas cinco foram autorizados recursos menores do que os $0,12 \%$ das Relações Exteriores (quais sejam: cultura, habitação, comunicações, energia, e desporto e lazer). Cabe ressaltar que $1,86 \%$ do Orçamento de 2010 foi alocado na Defesa Nacional. $^{7}$ 
Quando se considera, ainda, que parte significativa dos recursos alocados para as relações exteriores não é gasta no país, mas em suas representações no estrangeiro, temos um elemento adicional a explicar a comparativamente baixa disputa política pelo controle do Ministério das Relações Exteriores. É de se esperar, porém, que com a crescente politização da política externa do país, com o seu cada vez mais visível impacto distributivo no plano doméstico, este quadro possa vir a ser revertido algum dia.

Contudo, o insulamento tradicionalmente desfrutado pelo Itamaraty deve ser compreendido como derivado, também, de outros fatores. Como discutido com maiores detalhes por Faria (2008), essa centralização do processo de formação da política exterior no MRE é o resultado da confluência de distintos fatores, quais sejam: (a) do arcabouço constitucional do país, que concede grande autonomia ao Executivo nesta matéria, relegando o Legislativo a uma posição marginal, o que também ocorre na maior parte dos países; (b) do fato de o Congresso brasileiro ter delegado ao Executivo a responsabilidade pela formação da política externa; (c) do caráter "imperial" do presidencialismo brasileiro; (d) do fato de o modelo de desenvolvimento por substituição de importações ter gerado uma grande introversão e um insulamento dos processos políticos e econômicos do país, redundando em grande isolamento internacional do Brasil, reduzido a partir do início da década de 1990; (e) do caráter normalmente não conflitivo e largamente adaptativo da atuação diplomática do país; e, por fim, mas não menos importante, (f) da significativa e precoce profissionalização da corporação diplomática do país, associada ao prestígio de que desfruta o Itamaraty nos planos doméstico e internacional.

No entanto, a redemocratização do Brasil, a obsolescência do modelo de desenvolvimento por substituição de importações, o consequente adensamento das relações internacionais do país e a crescente politização da política externa brasileira, derivada de um maior ati- 
vismo no campo internacional de uma série de stakeholders do plano doméstico, são fatores que têm pressionado o Itamaraty no sentido da superação do modelo insular de produção da política externa. Nos termos de Nunes (1997), se o insulamento burocrático significa a redução do escopo da arena em que interesses e demandas extrainstitucionais podem desempenhar algum papel, o que se tem verificado no país desde a redemocratização, cada vez com maior intensidade, é a busca de ampliação do escopo dessa arena.

No plano internacional, os novos desafios e as oportunidades abertas ao Brasil, com o fim da Guerra Fria e com o recrudescimento e a subsequente fragilização da hegemonia norte-americana, têm demandado não apenas um maior ativismo da diplomacia do país, com a elaboração de uma agenda positiva de negociação (LIMA, 2000), mas também a maior legitimidade doméstica do posicionamento e das pretensões internacionais do Brasil, o que também deve ser visto como elemento a pressionar no sentido de uma política externa de maior capilaridade social e de mais amplo respaldo político no interior do país (LIMA, 2010). Com a inauguração da fase da "integração competitiva" da política externa do Brasil, que "politicamente corresponde à vigência da República Constitucional de 1988", a política doméstica passa a ter uma renovada importância

[...] no processo de formação da política externa, com duas implicações que se reforçam: a potencial diminuição da autonomia decisória prévia do MRE na condução da política externa e a politização da política externa, em função de seu novo componente distributivo, com a possibilidade da criação de novas coalizões favoráveis a mudanças do status quo, em face dos incentivos e restrições presentes nos planos doméstico e internacional (LIMA, 2000, p. 295).

Se o insulamento do Itamaraty é produto da confluência dos fatores listados acima, testemunham-se hoje, no país: (a) pressões no sentido 
de mudanças constitucionais que permitam um maior equilíbrio entre Executivo e Legislativo na produção da política exterior; (b) crescente ativismo do Congresso brasileiro no que se refere à política externa; ${ }^{8}$ (c) em lugar de uma autolimitação do presidente na matéria, a progressiva intensificação da chamada diplomacia presidencial, ou uma maior "presidencialização" da política externa (DANESE, 1999; CASON; POWER, 2009); (d) a superação do modelo de desenvolvimento substitutivo de importações, substituído pelo paradigma da inserção competitiva; (e) a ampliação do caráter conflitivo da atuação diplomática brasileira, em função da maior assertividade do país no plano regional e sistêmico, a despeito de uma postura internacional do Brasil predominantemente cooperativa e de valorização do multilateralismo; e, finalmente, (f) a erosão, bastante visível durante o governo Lula da Silva, da coesão da corporação diplomática, testemunhada, entre outros fatores, pela acidez do posicionamento de segmentos da corporação, notadamente diplomatas aposentados, amplamente veiculado pela mídia nacional.

Em resposta a esses desafios, por iniciativa própria ou constrangido por uma diversidade de atores e circunstâncias extracorporativas, o MRE tem, nos últimos anos, em paralelo ao adensamento de sua atuação internacional, multiplicado os seus esforços de coordenação intragovernamental, de articulação intergovernamental, no plano federativo, e de busca de cooperação intersetorial, ou seja, com os agentes do mercado e da sociedade civil, como será visto nas próximas seções. 9

Antes de avançarmos, porém, são necessárias algumas breves considerações de ordem conceitual. Como destacado por Souza (2006), no contexto de uma discussão acerca da problemática da gestão metropolitana, é importante distinguir "cooperação" de "coordenação", ambas envolvendo a negociação entre atores e instituições com preferências e objetivos eventualmente conflitantes. Segundo a autora: 
O Itamaraty e a Política Externa Brasileira: Do Insulamento à Busca de Coordenação...

\begin{abstract}
A cooperação é requerida quando existe autonomia formal dos entes que participam da ação coletiva e a coordenação quando os participantes compartilham a mesma fonte de autoridade, sendo, portanto, possível centralizar decisões, as quais têm um fluxo na direção "de cima para baixo" (SOUZA, 2006, p. 173).
\end{abstract}

Sendo assim, o Itamaraty busca coordenar as atividades dos demais atores e agências do governo federal em matéria de política externa, uma vez que todos compartilham a mesma fonte de autoridade, e cooperar com os governos subnacionais, que têm certa autonomia como entes federados, e com os agentes societários, que gozam de autonomia formal.

\title{
O Itamaraty e a Busca de Coordenação Intragovernamental na Produção da Política Externa
}

Cabe iniciarmos esta seção recordando que ainda que o Poder Executivo esteja, no Brasil, "todo concentrado na pessoa do presidente", ele delega, dada a impossibilidade prática da tarefa, autoridade aos ministros para a resolução de três problemas cruciais de coordenação das funções do Executivo, quais sejam: execução das políticas, integração dos diferentes departamentos administrativos do governo e também, muitas vezes, busca de apoio político no Congresso Nacional (LOUREIRO; ABRUCIO, 1999, p. 82). No que diz respeito à coordenação intragovernamental, porém, é de se esperar que a capacidade do ministro de produzi-la, bem como o seu grau de liberdade, dependa, também, não apenas da credibilidade e dos recursos técnicos e materiais do ministério e/ou da habilidade de seu responsável, mas também da relevância da política específica para o próprio presi- 
dente, ou para seu partido e/ou sua base de sustentação partidária, como destacado por Art (1973).

Dos 23 Ministérios do governo Lula da Silva (dados de junho de 2009), todos, à exceção do MRE, por motivos óbvios, e do Ministério da Integração Nacional, tinham instituídas Secretarias de Relações Internacionais, Diretorias ou Assessorias de Assuntos Internacionais, ou órgãos semelhantes. Ademais, todas as oito Secretarias que tinham status de Ministério também possuíam órgãos do gênero, bem como os seis outros órgãos do governo federal que desfrutavam o mesmo status. ${ }^{10}$

Esses dados ilustram um processo que tem sido denominado "horizontalização da política externa brasileira". Se muito tem se discutido acerca das crescentes demandas de atores da sociedade civil brasileira por maior participação na produção da política exterior do país, parece ainda significativa a lacuna nas pesquisas acerca da necessidade de coordenação intragovernamental para a produção das políticas públicas, notadamente da política externa. No âmbito mais geral, proliferam hoje, no governo federal, as Comissões Interministeriais, encarregadas do tratamento de uma grande diversidade de temas e da produção de inúmeras propostas de políticas. Como demonstrado por Figueira (2010), comparando os vinte anos anteriores à Constituição de 1988 às duas décadas posteriores, houve não apenas um aumento expressivo de Comissões Interministeriais, mas também do número daquelas de que participa o Itamaraty.

Silva et al. (2010, p. 31), por seu turno, demonstraram que, do ponto de vista normativo, a horizontalização da política externa brasileira é evidenciada pela atribuição de "competência em política externa para toda a estrutura do Poder Executivo federal brasileiro e não apenas ao MRE", competência essa não somente para a implementação das decisões, mas também para a formulação das políticas, "ao contrário do que se costuma afirmar". 
Se a legislação infraconstitucional, então, tem promovido uma dispersão de competências, ou esta "horizontalização legal" da política externa, que implica potencial competição, no âmbito intragovernamental, na produção de tal política, pesquisa realizada por França e Sanchez (2009) sugere o que os autores denominaram "verticalização pragmática”. Em suas palavras:

Apesar de quase nenhuma das regulamentações analisadas contar com previsão de cooperação com o MRE ou mesmo entre os ministérios e desses com a Presidência para a condução da política externa, os entrevistados confirmaram em sua totalidade contatos frequentes com o MRE. Exceções a essa regra foram indicadas em negociações muito técnicas. Portanto, a intuição da concentração de competências no MRE não está só no imaginário do cidadão comum, mas também daqueles que teriam competência para atuar autonomamente em temas de política externa.

A questão valorativa - se essa horizontalização legal e a verticalização pragmática são positivas ou negativas - ainda está pendente e certamente requer estudos detalhados e comparativos de casos e negociações específicas (FRANÇA; SANCHEZ, 2009, p. 2).

Os autores sugerem que esta "pulverização de responsabilidades na arena internacional" pode ser perigosa. Premido por essa pulverização, ou pela concorrência de outros atores do governo federal na seara internacional, o Itamaraty se vê hoje envolvido em uma grande variedade de atividades em parceria com esses outros atores, tanto a partir de sua própria iniciativa como demandado por outros ministérios e agências federais. Um mapeamento completo dessas parcerias ainda está por ser realizado.

Nesta seção, para ilustrar este processo, que demanda uma coordenação das ações, pelo menos segundo o ponto de vista do Itamaraty, se- 
rão discutidas, de forma exploratória, duas iniciativas: (a) a maneira como o Itamaraty tem tentado mobilizar e coordenar diversas instâncias do governo federal para a internalização das diretrizes de cooperação trilateral definidas no âmbito do Fórum IBAS (Índia, Brasil e África do Sul), estabelecido em 2003; e (b) a criação da figura do adido agrícola em algumas das embaixadas brasileiras. Essas duas iniciativas são interessantes por evidenciar, no primeiro caso, o ativismo do MRE no plano intragovernamental e, no segundo, por ter se tratado de uma proposta a respeito da qual o Itamaraty se viu forçado a ceder à pressão de outros atores, uma vez que a instituição parece ter sido, desde há muito, refratária à ideia.

Cabe recordarmos que tanto o IBAS, como componente da estratégia brasileira de conformação do eixo Sul-Sul no sistema internacional, quanto as questões relativas ao agronegócio eram do especial interesse do então presidente Lula da Silva. Tal centralidade na agenda presidencial pode ter também contribuído, no primeiro caso, para a conformação da densa teia de articulações intragovernamentais para a implementação das diretrizes do IBAS, também central para o próprio ministro das Relações Exteriores, e, no segundo caso, para fazer prevalecer, perante o Itamaraty, uma antiga demanda do Ministério da Agricultura e dos empresários do agronegócio. O propósito dos dois breves estudos de caso é ilustrarmos não apenas as múltiplas dimensões nas quais se evidencia, no plano intragovernamental, o desencapsulamento do MRE, mas também o seu caráter multifacetado e a sua ambiguidade, talvez inevitável.

\section{(a) Coordenação}

intragovernamental nos Grupos de Trabalho do Fórum IBAS ${ }^{11}$

É a partir dos Grupos de Trabalho (GTs) que se dá a internalização das diretrizes de cooperação trilateral definidas pelo Fórum IBAS. A sua estrutura e a sua dinâmica evidenciam a grande capilaridade in- 
O Itamaraty e a Política Externa Brasileira: Do Insulamento à Busca de Coordenação...

tragovernamental que pode ser demandada pela política externa, ou seja, a densa articulação doméstica algumas vezes imprescindível não apenas para a formulação da política exterior, mas também para a sua implementação. São os seguintes os ministérios diretamente envolvidos nos dezesseis GTs do IBAS: ${ }^{12}$ Ministério do Planejamento, Orçamento e Gestão (MPOG), Fazenda, Ministério da Agricultura, Pecuária e Abastecimento (MAPA), Cidades, Ministério da Ciência e Tecnologia (MCT), Ministério do Desenvolvimento, Indústria e Comércio Exterior (MDIC), Cultura, Defesa, Ministério do Desenvolvimento Social e Combate à Fome (MDS), Esportes, Ministério da Educação (MEC), Ministério de Minas e Energia (MME), Ministério do Meio Ambiente (MMA), Ministério da Saúde (MS) e Turismo. Há também o envolvimento de diversos outros órgãos e secretarias do governo federal.

Os Grupos de Trabalho do IBAS são gerenciados, em cada um dos três países, pelos chamados Pontos Nodais, que, no Brasil, são funcionários de alto escalão da burocracia federal, podendo ser lotados no próprio MRE ou em outros órgãos federais ou ministérios. Os Pontos Nodais atuam como coordenadores domésticos dos GTs, sendo designados para acompanhar e facilitar as atividades do Grupo, além de serem responsáveis pela coordenação das interações entre os representantes temáticos ou setoriais dos três países envolvidos no Fórum. Isso porque cada Grupo de Trabalho é formado por representantes dos três países, existindo, pois, um único GT do IBAS para cada uma das áreas em que se busca a cooperação, do qual participam representantes dos três países.

Os três países-membros do IBAS têm representação em todos os dezesseis GTs, muitos deles divididos em subgrupos. No Brasil, que nos interessa particularmente, os participantes são tanto funcionários do MRE quanto de outros ministérios e demais órgãos federais. Como nem sempre o MRE tem departamentos ou especialistas nas áreas de atuação dos GTs, o acompanhamento das atividades dos 
grupos fica, então, sob a responsabilidade de outro ministério ou órgão federal.

Para que possamos dimensionar a complexidade da tarefa de coordenação intragovernamental, sob a responsabilidade dos Pontos Nodais, devemos ter em mente, inicialmente, que cada GT funciona de maneira autônoma, tendo seu próprio ritmo de trabalho e formas de atuação. No que diz respeito ao plano intergovernamental, cabe ainda considerar as diferenças estruturais das burocracias dos três Estados, uma vez que o andamento dos trabalhos dos GTs pode ser obstaculizado ou facilitado pelas especificidades do aparato burocrático-administrativo específico de cada país e de cada setor de atuação do Fórum. No entanto, todos os GTs se encontram em um mesmo nível hierárquico dentro do organograma do IBAS.

Na estrutura organizacional da administração federal brasileira, todos os principais órgãos que compõem os GTs estão posicionados em um mesmo nível hierárquico, ou seja, são ministérios ou órgãos do executivo federal que atuam de modo independente, submetidos apenas à Presidência da República. Porém, se as clivagens organizacionais são temáticas, há que se considerar também, em função do presidencialismo de coalizão brasileiro, que essa estrutura é, em ampla medida, "loteada" entre os partidos que compõem a base política do presidente, o que agrega outro elemento complicador para os esforços de coordenação intragovernamental. Deve-se considerar, também, a existência de ministérios tradicionais, com burocracias e processos já consolidados, e outros de criação mais recente, o que sugere, por si só, modos de atuação mais ou menos cristalizados e, portanto, propensões diferentes ao insulamento e à cooperação. Há, assim, no âmbito dos GTs, dificuldades de coordenação e de acompanhamento das atividades, de diversas ordens, pesando também sobre o desenvolvimento das atividades dos grupos os interesses de cada órgão específico frente às necessidades relativas às ações de cooperação trilateral. 
Alexander (1993) afirma que sistemas interorganizacionais e intraorganizacionais devem buscar a coordenação de suas atividades quando seu escopo e sua complexidade crescerem a ponto de não mais estarem contidos nos limites do simples controle hierárquico. No caso da coordenação doméstica das ações de política externa, a multiplicação de temas da agenda internacional tem exigido, nos últimos anos, dos agentes formuladores e implementadores, a busca de intercâmbios e parcerias em áreas e setores técnicos mais específicos, justificando-se, desse modo, a multiplicidade de atores, intra e extragovernamentais, envolvidos nas atividades domésticas do Fórum IBAS.

A estrutura do governo para a implementação da política externa é constituída por um arranjo organizacional e por um corpo burocrático extremamente complexos, por organizações e funcionários que têm posições, percepções, interesses e incentivos muitas vezes distintos. Esta diversidade de organizações articuladas para a implementação das diretrizes da cooperação trilateral no âmbito do IBAS, considerando suas percepções, expectativas e seus distintos graus de expertise, pode gerar conflito de interesses e divergências no posicionamento dos atores governamentais. Alexander (1993) assinala que as estruturas de coordenação são particularmente necessárias quando há horizontalidade entre as organizações envolvidas, situação que ocorre no âmbito intragovernamental.

Dos dezesseis GTs do IBAS hoje existentes, cinco estão sob a coordenação direta do MRE, isto é, os Pontos Nodais são funcionários do Itamaraty (GTs de comércio, cultura, meio ambiente, transporte e turismo). Talvez se possa pensar que essas cinco áreas são precisamente, dentre as dezesseis cobertas pelos GTs, aquelas de interesse prioritário do MRE. Vale notarmos, ainda, que dos onze GTs que não estão sob a coordenação direta do Itamaraty, em apenas dois (assentamentos humanos e sociedade da informação) o Ponto Nodal não é parte da assessoria internacional, ou equivalente, do Ministério ou 
outro órgão federal responsável pelo GT. Este dado é significativo porque indica que os trabalhos estão sendo coordenados por pessoas que, mesmo não fazendo parte do corpo de funcionários do MRE, provavelmente têm interações frequentes com o Itamaraty, em razão de suas próprias atividades em seus órgãos de origem. Ademais, vale recordarmos que a Fundação Alexandre de Gusmão (FUNAG), vinculada ao MRE, ministra Cursos de Capacitação em Relações Internacionais especificamente para altos funcionários do governo federal, das autarquias e das agências reguladoras, cursos esses que têm, por certo, não apenas o objetivo de prover capacitação, mas também de produção de visões e interesses convergentes e de expansão e consolidação de uma rede intragovernamental de especialistas que tenha o Itamaraty como instituição de referência.

A "horizontalização da política externa brasileira", que é tanto legal como organizacional, deve ser vista, obviamente, como evidência clara da perda de monopólio do Itamaraty sobre a agenda internacional brasileira, derivada do indefectível processo de globalização, da consequente fragilização generalizada das fronteiras entre o doméstico e o internacional, e do adensamento das relações internacionais do país. Contudo, como evidenciado pela experiência de implementação das diretrizes do IBAS no país, o MRE parece estar atuando intensamente no sentido da ampliação de sua capacidade de coordenação interministerial. Dito de outra maneira, o que pode ser visto como concorrência intragovernamental na definição da agenda internacional do país e de sua política externa parece estar redundando em uma maior atenção do MRE não apenas aos atores societários, mas também ao plano intragovernamental.

\section{(b) A criação dos adidos agrícolas nas embaixadas brasileiras}

Pelo Decreto Presidencial No. 6.464, de 27 de maio de 2008, foi criada a figura do adido agrícola em algumas representações brasileiras 
no exterior, quais sejam: Buenos Aires, Bruxelas, Genebra, Moscou, Pequim, Pretória, Tóquio e Washington. O adido exerce missão permanente de assessoramento em assuntos agrícolas junto às referidas missões diplomáticas. Suas diversas atribuições incluem: busca de ampliação do acesso dos produtos do agronegócio brasileiro aos mercados local ou regional; prospectar novas oportunidades; analisar o mercado local e as suas tendências; apoiar a promoção externa desses produtos; e monitorar os problemas que possam afetar esse comércio e as políticas locais específicas de interesse do agronegócio brasileiro.

Trata-se de uma antiga reivindicação tanto da iniciativa privada e de suas representações quanto do Ministério da Agricultura, Pecuária e Abastecimento (MAPA). Há, na verdade, registro de reivindicações semelhantes datando de inícios da década de 1950. Várias fontes ouvidas pela imprensa relataram a resistência do Itamaraty à ideia. Roberto Rodrigues, por exemplo, ex-presidente da Associação Brasileira do Agronegócio (Abag) e ministro da Agricultura do governo Lula da Silva antes da criação da figura do adido agrícola, criticava o "bloqueio do MRE à ideia". O presidente da Sociedade Rural Brasileira afirmou que o MRE sempre foi "excelente politicamente, mas deixa a desejar em termos comerciais" (EXPORTADORES..., 2004).

Produtores e exportadores brasileiros conhecem bem o papel desempenhado no Brasil por adidos agrícolas de diversos países e, na medida em que o agronegócio brasileiro foi ampliando a sua competitividade no mercado internacional, cresceram também os problemas na comercialização externa de seus produtos, sentidos diretamente pelo setor privado. A iniciativa finalmente aprovada, de criação dos adidos em embaixadas brasileiras selecionadas, dá ao MAPA maior possibilidade de coordenação com o MRE nas negociações internacionais relativas ao agronegócio.

De acordo com o que foi apurado pela mídia brasileira, nas negociações que antecederam a decisão de criação da figura dos adidos agrí- 
colas, o Itamaraty resistia à ideia por temer nomeações políticas, por não desejar o título de "adido" e porque queria que os ocupantes dos cargos recebessem treinamento específico (BRASIL..., 2008). Essa resistência reflete o temor, amplamente disseminado no Itamaraty, de fragmentação do serviço exterior brasileiro e de prevalência eventual de interesses setoriais, em detrimento de uma capacidade, quase monopolizada pela corporação diplomática, segundo a visão da própria instituição, de pautar as negociações internacionais pelo "interesse nacional". Temia-se, também, que o recrutamento de adidos de fora dos quadros diplomáticos abrisse precedente tido como não desejável, uma vez que poderia acarretar imprevisíveis desdobramentos futuros.

Os termos do Decreto de criação dos adidos, contudo, evidenciam que algumas das preocupações do Itamaraty foram contempladas. A blindagem do cargo às nomeações políticas é um exemplo. Dentre outras exigências, o adido deve ser "servidor público federal ocupante de cargo efetivo do quadro de pessoal do Ministério da Agricultura, Pecuária e Abastecimento" ou empregado do quadro efetivo de empresa pública ou de sociedade de economia mista federais, desde que cedido ao MAPA. Sua designação para o cargo é da responsabilidade do presidente, "mediante indicação do Ministro de Estado da Agricultura, Pecuária e Abastecimento, ouvido, previamente, o Ministério das Relações Exteriores". Outra exigência dos ocupantes do cargo é "ter concluído curso de preparação para o exercício da missão de assessoramento em assuntos agrícolas, organizado e ministrado pelo Instituto Rio Branco, do MRE, em colaboração com o MAPA" (BRASIL, 2008). Evidencia-se aqui, uma vez mais, a estratégia usada pelo Itamaraty de procurar garantir, se não o seu monopólio sobre as negociações, cada vez mais impraticável, pelo menos a sua influência, pela via da oferta de capacitação, que implica também a constituição de uma rede intragovernamental que tenha o MRE como instância referencial. 
O Itamaraty e a Política Externa Brasileira: Do Insulamento à Busca de Coordenação...

Cabe, por fim, considerarmos que, se a criação dos adidos agrícolas é uma demanda antiga, defendida fortemente nos anos FHC, entre outros por Roberto Rodrigues, que viria a ser ministro da Agricultura do governo Lula da Silva, a decisão final só seria tomada em 2008. O Itamaraty parece ter resistido de distintas maneiras. Informações da imprensa sobre os bastidores das negociações interministeriais, que duraram meses, sugerem que o ministro da Agricultura teria afirmado que ele obteve da então ministra da Casa Civil, Dilma Rousseff, a aprovação à iniciativa. Talvez tenha sido a intervenção do círculo palaciano, então, o fator decisivo para a superação das resistências do MRE. As negociações, contudo, levaram a uma solução, como está claro no Decreto, que procura vincular as atribuições e responsabilidades do adido agrícola, considerado membro da missão diplomática brasileira no país, tendo inclusive direito ao passaporte diplomático, tanto ao MAPA quanto ao MRE. Definiu-se um compartilhamento de responsabilidades que passa, até mesmo, por uma repartição dos gastos, ficando o MAPA responsável pelas despesas com os eventuais auxiliares dos adidos agrícolas nas missões diplomáticas. Perdido o anel, procurou-se a preservação do dedo.

\section{O Ministério das Relações Exteriores e a Cooperação Federativa: Promovendo e Tutelando as "Ações Internacionais" dos Governos Subnacionais}

Uma pesquisa recente, realizada pela Confederação Nacional de Municípios (CNM), nos ajuda a dimensionar o crescente ativismo dos governos subnacionais brasileiros no campo internacional, cujas motivações não nos cabe aqui discutir. Note-se que essa pesquisa atesta o diagnóstico virtualmente unânime dos pesquisadores brasileiros sobre o assunto. A investigação da CNM constatou que, ao fi- 
nal das gestões municipais de 2005 a 2008, apenas trinta das 5.562 prefeituras investigadas possuíam algum órgão estruturado dedicado à área internacional. Das demais, 116 possuíam um servidor responsável por assuntos internacionais e 3.419 tinham "interesse pela temática" (CONFEDERAÇÃO NACIONAL DE MUNICÍPIOS, [s.d.]a). Das 26 capitais brasileiras, apenas dez tinham um setor específico responsável pela área internacional, ao passo que, entre as outras, onze possuíam um responsável pelos assuntos internacionais e cinco tinham apenas interesse pelo assunto. No que diz respeito aos estados, em termos absolutos, São Paulo é o estado brasileiro com o maior número de prefeituras com estruturas específicas encarregadas da área internacional ou servidor responsável, seguido pelo Rio Grande do Sul e por Minas Gerais. Em termos proporcionais, computando-se o número de municípios de cada estado, Roraima apareceu em primeiro lugar, seguido de Rio de Janeiro e São Paulo. Outro dado importante é que apenas 227 prefeituras do país declararam já ter realizado algum projeto de cooperação internacional (ou seja, $4 \%$ dos municípios brasileiros).

Constatado o interesse generalizado dos municípios do país por uma maior atuação na seara internacional, a Confederação criou, em 2006, a CNM Internacional, "responsável por promover a inserção internacional dos municípios brasileiros" (CONFEDERAÇÃO NACIONAL DE MUNICÍPIOS, [s.d.]b) ofertando, entre outros, assessoria política internacional ao movimento municipalista brasileiro. Se o país testemunha a expansão autóctone das ações internacionais dos governos subnacionais, inauguradas, de maneira institucionalizada, com a criação da Secretaria Especial para Assuntos Internacionais do governo do estado do Rio Grande do Sul, em 1987, este respaldo da Confederação talvez tenha o potencial de acelerar um processo que, mesmo ainda incipiente, vem crescendo de maneira não desprezível.

O Itamaraty não está alheio a esse processo, ainda que, segundo a apreciação de alguns autores, como Saraiva (2006), o assunto tenha 
O Itamaraty e a Política Externa Brasileira: Do Insulamento à Busca de Coordenação...

chegado tarde à chancelaria. Ademais, como afirma o autor, o Estado central "não aprecia a ideia da fragmentação da autoridade nas questões internacionais".

A tese da iminência do descontrole interno e a hipótese das dificuldades que emanariam da descentralização coordenada na formulação de políticas públicas com impacto internacional são comuns na burocracia federal, particularmente do Itamaraty e do Banco Central (SARAIVA, 2006, p. 434).

As iniciativas do Itamaraty em resposta ao ativismo dos governos subnacionais, em larga medida adaptativas, como apontam diversos autores, foram inicialmente coordenadas pela Assessoria de Relações Federativas, criada em 1997, por determinação expressa do então presidente Cardoso. Essa determinação presidencial ilustra o fato de que o desencapsulamento do MRE tem distintas fontes. Em 2003, essa Assessoria foi transformada em Assessoria Especial de Assuntos Federativos e Parlamentares (AFEPA), unificando as estruturas do Itamaraty, antes isoladas, de interação com os governos subnacionais e aquela responsável pelas relações parlamentares. Neste ponto, vale recordarmos a criação, já no governo Lula da Silva, da Subchefia de Assuntos Federativos da Presidência da República, que, no que diz respeito ao interesse de projeção internacional dos governos subnacionais, tem chamado para si iniciativas que talvez o Itamaraty preferisse ver sob o seu comando direto. ${ }^{13}$

É interessante notarmos, contudo, que dois dos Escritórios Regionais do Itamaraty, o ERESUL e o ERENE, criados em 1995 no Rio Grande do Sul e em Recife, respectivamente, foram constituídos antes da Assessoria de Relações Federativas, que foi instituída, como visto, em 1997.

No Brasil, como na maior parte dos países, observa-se uma tendência de as ações internacionais dos governos subnacionais se concentra- 
rem em atividades relativas a low politics, tendo, portanto, baixo potencial de conflito com a política exterior do Estado nacional. Mesmo os estados e municípios brasileiros não sendo sujeitos do direito internacional público, eles atuam, cada vez com maior intensidade, na cooperação internacional, firmando acordos de natureza econômica e cultural, com distintos graus de formalidade (VIGEVANI, 2006, p. 130).

Se o principal objetivo expresso, desde a criação da primeira assessoria específica, em 1997, é oferecer assessoramento e respaldo aos governos subnacionais em matéria internacional, buscando também canalizar "demandas para a formulação da política externa" (PEREIRA, 2004, p. 149), transparece, na atuação do Itamaraty, a preocupação estratégica de "integrar as iniciativas e prioridades de estados e municípios ao processo de identificação dos grandes interesses nacionais" (Conselheiro M.C. Moura Daniel, 2002, apud VIGEVANI, 2006, p. 133). Note-se que, na "opinião do Itamaraty, apenas os Estados desenvolvem e conduzem política externa stricto sensu, as localidades limitam-se a realizar ações internacionais" (PEREIRA, 2004, p. 150).

No plano da cooperação federativa em matéria internacional que o Itamaraty tenta promover, têm papel de destaque os oito Escritórios Regionais do MRE, subordinados à AFEPA, quais sejam: EREMINAS (Escritório de Representação em Minas Gerais); EREPAR (Escritório de Representação no Paraná); ERESC (Escritório de Representação em Santa Catarina); ERESUL (Escritório de Representação no Rio Grande do Sul); ERERIO (Escritório de Representação no Rio de Janeiro); ERESP (Escritório de Representação em São Paulo), todos com sede nas capitais dos respectivos estados, e o ERENOR (Escritório de Representação na Região Norte, antigo EREMA), com sede em Manaus, e o ERENE (Escritório de Representação no Nordeste), com sede em Recife. Levantamento realizado pelo autor deste trabalho mostra que é crescente o ativismo desses es- 
O Itamaraty e a Política Externa Brasileira: Do Insulamento à Busca de Coordenação...

critórios, criados entre 1995 e 2004. A despeito dessas iniciativas do Itamaraty, porém, Saraiva (2006, p. 450) afirma que o Brasil tem, entre os países federativos, "uma das mais centralizadas formas de ação externa do Estado", o que o autor atribui, também, ao "conservadorismo corporativo do Itamaraty" (SARAIVA, 2006, p. 452).

Cabe destacar que, não obstante as críticas, os Escritórios Regionais do MRE buscam cooperar, em uma vasta gama de assuntos internacionais, não apenas com os governos subnacionais, mas também com toda a sorte de atores societários, indivíduos e organizações. Não se restringindo à cooperação com estados e municípios, os Escritórios Regionais devem, assim, ser pensados também como parte da estrutura montada pelo Itamaraty para a produção da cooperação intersetorial no âmbito da política externa, como se verá em maior detalhe na seção subsequente deste trabalho.

Porém, como observa Vigevani (2006, p. 130), "a adaptação institucional do governo central para incluir as instâncias regionais é fraca”. Formulando a hipótese de que, na seara internacional, os municípios brasileiros gozariam de maior liberdade de ação do que os estados, Salomón e Nunes (2007) notam que a ação externa do governo do estado do Rio Grande do Sul parece inspirada, "tanto em estruturas e procedimentos como em substância", na do governo central. "A estrutura institucional do seu aparato paradiplomático [do governo do RS] - desenvolvido inicialmente segundo o modelo do MRE -, a complexidade da agenda e a primazia dos interesses econômicos sobre os sociais como principais propulsores das políticas assim parecem demonstrá-lo" (SALOMÓN; NUNES, 2007, p. 140). Aqui, como no caso da "horizontalização" da política externa no âmbito do governo federal, desejo e possibilidade, ainda que relativa, de ação autônoma dos atores no plano internacional parecem, de certa forma, condicionados pela própria centralidade do Itamaraty, talvez em função do prestígio que ele ainda desfruta e da própria cooperação ofertada, de caráter supervisor e em certa medida tutelar. Tutelar, posto 
que se objetiva, também, monitorar a atuação internacional dos governos subnacionais para garantir que ela não constranja a atuação do próprio MRE. No entanto, e como contraponto, cabe notarmos que a "pressão política direta dos governadores na direção do Poder Executivo federal ou do Congresso Nacional vem sendo a forma mais explícita do agir das unidades subnacionais", as quais, apesar dos constrangimentos, têm, de acordo com Saraiva (2006, p. 443), demonstrado "criatividade e movimento no plano internacional", com expressivo grau de competência técnica, pelo menos no que diz respeito ao comércio exterior, ainda segundo o mesmo autor.

\section{O Itamaraty: Cooperação Intersetorial e Diplomacia Pública}

Devemos agora, por fim, analisar a maneira como o desinsulamento do Ministério das Relações Exteriores tem se dado no plano intersetorial, ou seja, no que diz respeito à articulação do governo federal (primeiro setor) com as entidades do mercado (segundo setor) e com a sociedade civil (onde proliferam as entidades do terceiro setor). Trata-se, aqui, de uma discussão que não se pretende exaustiva, tendo o objetivo de apenas ilustrar um processo em curso, ainda não discutido de maneira mais sistemática no âmbito acadêmico, mas que merece maior atenção.

Neste âmbito das articulações intersetoriais, ou seja, das interações do Itamaraty com as entidades do mercado e da sociedade civil, as evidências, no entanto, parecem contraditórias. No primeiro caso, das interações com as entidades do mercado, Oliveira e Pfeifer (2006) afirmam ter havido não apenas uma mudança no padrão de relacionamento entre o Itamaraty e o empresariado durante o governo Lula da Silva, mas também uma certa retração, após um processo de maior institucionalização das interações durante o governo precedente, a despeito do fato de que, em "alguns aspectos, houve uma 
O Itamaraty e a Política Externa Brasileira: Do Insulamento à Busca de Coordenação...

aproximação estreita e resultados auspiciosos" (OLIVEIRA; PFEIFER, 2006, p. 400). Seja como for, no caso do relacionamento entre primeiro e segundo setor, no plano da política externa, a literatura existente é quase unânime ao enfatizar a vigência de interações ainda aquém das desejáveis. Tais interações, porém, não serão discutidas aqui em maior detalhe. Parece possível sugerirmos, não obstante, que se o governo Lula da Silva cultivou estreita proximidade com diversos segmentos do setor empresarial, em searas outras que não a da política externa, o governo brasileiro, e também o Itamaraty, ao priorizar a internacionalização das grandes empresas do país, em franca sintonia com suas próprias estratégias de busca de reposicionamento do Brasil no sistema internacional e de promoção do chamado eixo Sul-Sul, procurou estabelecer parcerias seletivas com o empresariado, reforçando, por outro lado, a diplomacia pública no plano doméstico. ${ }^{14}$

No que diz respeito às articulações do Itamaraty com a sociedade civil, parece pertinente sugerirmos uma sensível ampliação da diplomacia pública durante o governo Lula da Silva, não apenas no sentido tradicional do termo, de projeção de uma dada imagem do Brasil no exterior, mas também de divulgação da política externa do país no âmbito doméstico. É esta segunda vertente da diplomacia pública brasileira que nos interessa aqui mais especialmente. Nesse campo, discutiremos, a seguir, a criação do canal oficial do MRE no YouTube, a presença de autoridades do Itamaraty na mídia escrita e, por fim, a intensificação do papel desempenhado pela FUNAG, que envolve também a busca de um maior diálogo com a crescente comunidade brasileira de especialistas acadêmicos em relações internacionais e política externa.

\section{(a) O MRE no YouTube}

No canal oficial do Ministério das Relações Exteriores no YouTube (http://www.youtube.com/mrebrasil), é possível ter acesso a vídeos 
e áudios de programas, entrevistas e coletivas de imprensa do ministro de Estado, diplomatas e outras autoridades sobre temas de política externa. A página é relativamente nova (foi criada em 18 de fevereiro de 2009), mas já tem 470 vídeos. O canal, que já foi visitado 490.179 vezes (dados do dia 16 de abril de 2012, às 17 horas), tem o claro objetivo de aproximar os usuários do YouTube das notícias da política externa brasileira, bem como informá-los sobre as atividades do Itamaraty, especialmente aquelas do ministro de Estado.

O fato de o MRE ter um espaço no sítio de vídeos mais popular do mundo revela ainda o objetivo, por parte da instituição, de aproximar-se da sociedade em busca da legitimação da política externa. Recorde-se que, nos últimos anos, a política exterior do país tem, por vezes, suscitado grandes controvérsias no plano doméstico, como, por exemplo, quando da resposta brasileira, para muitos excessivamente complacente, à nacionalização dos hidrocarburetos pelo presidente boliviano ou no que concerne à incorporação da Venezuela ao Mercosul e ao relacionamento do Brasil com o Irã.

De acordo com a Embaixada Brasileira em Washington, "o objetivo [do canal do MRE no YouTube] é permitir que jornalistas, acadêmicos e todo o público interessado em assuntos de política externa brasileira tenham acesso a gravações em vídeo de coletivas de imprensa, entrevistas, briefings e visitas de autoridades ao Palácio do Itamaraty" (EMBAIXADA BRASILEIRA EM WASHINGTON, [s.d.]).

\section{(b) A divulgação da política externa do país na mídia impressa}

Com a crescente politização da política externa brasileira, tornou-se comum, pelo menos desde o governo Fernando Henrique Cardoso, que o ministro das Relações Exteriores e outras autoridades do Itamaraty venham a público explicitar motivações, compartilhar per- 
cepções e sensibilizar o público doméstico quanto às oportunidades e constrangimentos do momento, em busca de respaldo e legitimidade. Afinal, como nos lembra Putnam (1988), legitimidade e apoio domésticos ampliam a capacidade de barganha no plano internacional, além, é claro, podemos acrescentar, de serem fundamentais na busca de superação das clivagens intragovernamentais e das divergências político-partidárias no âmbito doméstico.

Dada a dificuldade de uma quantificação plenamente confiável deste fenômeno de publicização de pontos de vista e estratégias por parte das lideranças do MRE, apresentamos a seguir alguns dados, certamente parciais, até por não estabelecer comparações com períodos anteriores, mas que parecem ilustrativos. A quantidade de artigos e entrevistas do ex-ministro Celso Amorim publicados na mídia impressa do país, que teve uma média anual de 32,5 em 2003-2004, caiu para 12,5 em 2007-2008 (há apenas oito artigos/entrevistas publicados em 2008). O período de 2009-2010 teve uma média anual de nove artigos/entrevistas. A quantidade de artigos/entrevistas do ministro Antônio Patriota publicados na mídia impressa do país chegou a seis, da sua posse, em $1^{\circ}$ de janeiro de 2011 , até 16 de maio de 2011 , sem contarmos, aqui, aqueles veiculados na mídia estrangeira. ${ }^{15}$

Parece evidente que uma agência plenamente insulada dificilmente se daria ao trabalho deste tipo de exposição. Por outro lado, e talvez paradoxalmente, é igualmente possível argumentarmos que um certo grau de transparência possa ser demandado não apenas para se garantir respaldo e legitimidade, mas também para a preservação de alguma forma de autonomia, ou seja, como estratégia de resistência ao desinsulamento. No âmbito organizacional, contudo, assim como no governamental, como nos ensinou Nunes (1997), parece possível pensarmos que estas duas "gramáticas", a do universalismo de procedimentos e a do insulamento burocrático, convivam e combinem-se "como um ato de malabarismo". 


\section{(c) A Fundação Alexandre de Gusmão: think tank e diplomacia pública}

No que diz respeito às interações entre o Ministério das Relações Exteriores e a sociedade, a FUNAG, vinculada ao Ministério e criada em 1971, cumpre hoje um papel considerado estratégico. Em um balanço feito pela Fundação, em sua Newsletter de 18 de junho de 2009, são listadas as inúmeras atividades realizadas em 2008 com o intuito de "popularizar a política internacional", de "aproximar a política internacional do cotidiano do cidadão". 16 Nas palavras de seu presidente, "um dos objetivos da FUNAG é criar canal direto entre o mundo acadêmico, o diplomático e a sociedade civil. Porque não se legitima uma política externa sem que o cidadão tome conhecimento dessa política". Contudo, mais do que "socializar as ações do MRE", pretende-se também, pelo menos no plano do discurso, subsidiá-las.

Parece evidente, porém, a possibilidade de se pensar a atuação da FUNAG apenas como diplomacia pública ou como mera busca de legitimação dos cursos de ação e das estratégias capitaneadas pelo MRE. Contudo, uma postura menos crítica também encontrará respaldo para uma interpretação do ativismo da Fundação como forma de desencapsulamento institucional, ou seja, também como busca de incorporação de novos aportes extrainstitucionais, de fora da ainda fechada corporação diplomática brasileira.

Os números do balanço feito pela FUNAG são, por certo, expressivos: em 2008, a Fundação "publicou 116 títulos, realizou 20 eventos, ministrou cinco cursos e criou bibliotecas em todas as regiões do país". Dentre os eventos, destacam-se a I Conferência das Comunidades Brasileiras no Exterior e aqueles dedicados à promoção da interlocução entre a diplomacia e o mundo acadêmico do país. Ademais, todas as 620 obras até então publicadas pela FUNAG se encontram disponíveis, integralmente, na internet. Cabe ressaltarmos, tam- 
bém, dois programas da Fundação que "distribuem livros gratuitamente para que a população tome conhecimento da política externa brasileira". Ainda conforme a Newsletter de 18 de junho de 2009: "Na Literatura de Cordel, a história de diplomatas brasileiros é contada em rimas, de maneira simples e direta. O Livro na Rua fala de temas relacionados à política externa brasileira e também reúne biografias de diplomatas, em textos curtos e simples."

Por estas razões, parece pertinente denominarmos a Fundação como um think tank especializado em política externa, cujo impacto, contudo, é de difícil mensuração. Um think tank singular, devemos ressaltar, posto que não conta com unidade de pesquisa própria. Vale recordarmos, porém, que o Instituto de Pesquisa de Relações Internacionais (IPRI) é instituição vinculada à FUNAG. No entanto, no discurso e na prática de difusão doméstica da política externa, subsistem traços do ethos tradicional da diplomacia do país. Se a FUNAG assume explicitamente, como vimos, o seu objetivo de legitimação dos cursos de ação adotados pelo MRE, cabe destacarmos algumas outras questões que nos parecem também relevantes.

A Newsletter da Fundação Alexandre de Gusmão era intitulada, até recentemente, "Diplomacia ao alcance de todos". Se o seu objetivo é promover a divulgação das atividades e dos estudos patrocinados pela Fundação, a logomarca que o Boletim exibia até o início do ano de 2009 não deixa de guardar certa ironia. O título da Newsletter estava estampado sobre uma ilustração muito interessante: das alvas nuvens de um belo céu azulado, surgiam duas mãos, cujos indicadores se tocavam, produzindo luz. Trata-se, obviamente, de apropriação de uma cena do célebre afresco de Michelangelo, do teto da Capela Sistina, no Vaticano, em que Deus, das alturas, toca um homem, representando a criação de Adão. Esta logomarca tinha, por certo, o potencial de alimentar os muitos críticos do insulamento do Itamaraty, porque, independentemente de qualquer intencionalidade não explicitada, os objetivos do Boletim podiam ser interpretados, no seu 


\section{Carlos Aurélio Pimenta de Faria}

intuito de colocar a "Diplomacia ao alcance de todos", como benevolência das divindades. Dada a margem para interpretações como essa, talvez tenha sido hábil a retirada da logomarca.

Os críticos também encontrarão munição nos dois programas, mencionados acima, de distribuição gratuita de livros, uma vez que, como está claro na citação de há pouco, o conteúdo de alguns dos títulos distribuídos pode ser interpretado como mera hagiografia.

Deixando ao leitor a interpretação que lhe aprouver, devemos destacar duas outras iniciativas da Fundação, nas quais, a nosso ver, o intuito de busca de influência ou projeção de poder transparece com clareza, no primeiro caso no plano regional e, no segundo, no âmbito intragovernamental. Refiro-me ao Curso para Diplomatas Sul-Americanos, o qual, segundo a mesma fonte, já teria formado 120 diplomatas, e aos Cursos de Capacitação em Relações Internacionais ministrados para "altos funcionários do governo federal, das autarquias e das agências reguladoras". A frase subsequente da Newsletter merece ser citada integralmente: os "temas e as demandas são avaliados de acordo com as necessidades observadas pelo embaixador Celso Amorim, ministro das Relações Exteriores".

No que diz respeito ao papel da FUNAG, portanto, independentemente da postura a ser adotada pelo analista externo, mais ou menos crítica, compreendendo a sua atuação como mais ou menos unidirecional, de exclusiva busca de legitimação ou de valorização de um intercâmbio capaz de subsidiar a ação diplomática, acredito ser pertinente considerar que o grande ativismo da Fundação possa ser pensado como mais uma evidência, ainda que ambígua, da busca de desencapsulamento do Itamaraty. Uma tal interpretação está, certamente, na contracorrente da concepção, ainda perceptível no meio acadêmico brasileiro, de um insulamento olímpico, onisciente e autocongratulatório da instituição. 
Antes de encerrarmos a seção, porém, cabe recordarmos que o programa criado pelo Ministério da Educação, por intermédio da CAPES, para o desenvolvimento da pós-graduação stricto sensu em Relações Internacionais no país, intitulado "Programa Santiago Dantas de apoio ao ensino de RI', contou também com a parceria do MRE. A execução do programa ocorreu entre os anos de 2001 e 2004. Essa parceria pode, por certo, ser vista como indício de que ganha espaço, na corporação diplomática brasileira, a percepção de que sua autossuficiência do passado poderia, hoje, subsistir apenas em detrimento do próprio interesse nacional. Para exemplificar o ponto, podemos recordar que os vitoriosos painéis do açúcar e do algodão capitaneados pelo Brasil no âmbito da Organização Mundial do Comércio tiveram que se valer de consultores estrangeiros.

Outro dado importante no contexto desta discussão é a criação, por parte do Instituto Rio Branco, do MRE, do "Programa de Ação Afirmativa do IRB - Bolsa-Prêmio de Vocação para a Diplomacia”. Tal programa, instituído em 2006, tem como objetivo "ampliar as oportunidades de acesso aos quadros do Ministério das Relações Exteriores e incentivar e apoiar o ingresso de afrodescendentes (negros) na Carreira Diplomática, mediante a concessão de bolsas-prêmio destinadas ao custeio de estudos preparatórios ao Concurso de Admissão à Carreira Diplomática" "17 (MRE/IRB e MCT/CNPq, edital de 19 de outubro de 2006, disponível na internet).

As mudanças no processo seletivo para o ingresso no Instituto Rio Branco, que, no início de 2005, decidiu retirar o caráter eliminatório da língua inglesa do concurso de admissão à carreira, levaram a um intenso debate público que, segundo Moura (2006, p. 20), revelava também a generalizada percepção do Itamaraty como elitista, a despeito de o recrutamento dos novos diplomatas ser feito, há décadas, por meio de concurso público e do "crescente esforço para ampliar as bases de recrutamento para a carreira". Contudo, não obstante a "manutenção de um ethos aristocrático" na Casa de Rio Branco, como 
destacado por Moura (2006, p. 32), o Itamaraty também deseja veicular a sua imagem como uma "instituição democrática e representativa da população nacional". Essa intenção é demonstrada, por exemplo, pelo Programa de Ação Afirmativa do Instituto Rio Branco. A incorporação de um número mais significativo de afrodescendentes aos quadros do Itamaraty parece também atender tanto objetivos internacionais, uma vez que a diplomacia do país busca hoje, uma vez mais, fazer do Brasil um porta-voz do mundo em desenvolvimento, quanto domésticos, como, por exemplo, no sentido da superação do estigma de elitismo. Sendo elitismo (ou ethos aristocrático) e pluralismo racial expressões possíveis do insulamento burocrático e do universalismo de procedimentos, respectivamente, vemos, uma vez mais, que distintas gramáticas convivem hoje na instituição.

Quando se trata, como neste trabalho, de discutir o ambíguo processo de desencapsulamento do Itamaraty, é importante recordarmos também a significativa expansão, nos últimos anos, do quadro de diplomatas do MRE. O número de admitidos à carreira diplomática subiu de 32, no ano de 2005, para 105 por ano em 2006, 2007, 2008 e 2009. No ano de 2010 foram abertas 108 vagas e, em 2011, o número de vagas caiu para $26 .{ }^{18}$ No período de 2006 a 2010, aumentou em aproximadamente $50 \%$ o quadro de diplomatas brasileiros.

Essa expansão, além de ampliar a capacidade do Itamaraty de se fazer presente no cenário internacional e de possibilitar a melhoria de sua interlocução com os atores domésticos, governamentais e não governamentais, é significativa também em função de seu possível impacto intraorganizacional. Isso porque é de se esperar que os jovens diplomatas, em número tão mais expressivo, não consigam ser "socializados" à maneira dos antigos, o que pode resultar, no futuro, em um ethos corporativo menos acentuado e em menor coesão do corpo diplomático. ${ }^{19}$ Talvez o fato de essas turmas ampliadas do Instituto Rio Branco serem também chamadas, internamente, de "overbooking”, "coração de mãe" e "101 dálmatas" (BECKER, 
O Itamaraty e a Política Externa Brasileira: Do Insulamento à Busca de Coordenação...

2011) possa ser interpretado como tendo implicações para além do gracejo.

\section{Considerações Finais}

Em julho de 2007, o jornal Correio Braziliense publicou uma série de reportagens, assinada por Cláudio Dantas Sequeira, relatando/denunciando o fato de, entre 1966 e 1985, o Itamaraty ter operado um "poderoso serviço de inteligência, criado e operado pela cúpula do MRE", denominado Centro de Informações do Exterior (Ciex), que teria sido a "primeira agência criada sob o guarda-chuva do Sistema Nacional de Inteligência (SNI)". Tendo vasculhado o "arquivo secreto do Ciex", o jornalista constatou:

A escassez de evidências da participação da diplomacia brasileira na repressão fez crer a todos que o MRE foi a reserva moral da democracia, em pleno regime militar. Construiu-se, com o silêncio, a imagem de diplomatas sem partidos ou tendências ideológicas, incólumes aos vaivéns da política e dedicados exclusivamente à defesa do interesse do Estado. Mas não é bem assim. A cúpula do Itamaraty se ajustou perfeitamente aos interesses do governo militar, e o Ciex contribuiu de maneira decisiva para a localização e detenção de muitos asilados (SEQUEIRA, 2007).

Esta surpreendente e tardia revelação complementa a argumentação feita por Barros (1986) acerca dos elementos que explicam a proximidade entre militares e o Itamaraty durante o regime militar, tendo sido mais explorada, posteriormente, por Almeida (2008) e Penna Filho (2009).

O fato de tal “colaboração" ter passado despercebida por tantas décadas denota não apenas como pouco se sabia sobre o Itamaraty, mas também a postura de autoproteção da corporação diplomática do 
país, sempre empenhada não somente na produção da política externa, mas também na sua divulgação e na reflexão sobre a sua prática profissional. Note-se de passagem, porém, que hoje as reportagens do Correio Braziliense estão disponíveis no próprio sítio oficial do MRE. $^{20}$

No entanto, durante o governo Lula, o Itamaraty viveu um período, se não de intensificação de seus dissensos internos, certamente de sua inédita explicitação para o universo extracorporativo. Tornaram-se frequentes as manifestações públicas, principalmente por parte de diplomatas aposentados, de repúdio aos métodos, objetivos e prioridades da cúpula do MRE. Questionava-se o impacto da suposta ideologização e/ou partidarização da política externa do país, a qual, no governo Lula da Silva, bem como no de Dilma Rousseff, tem a sua formulação mais claramente compartilhada entre a cúpula do Itamaraty e a Presidência da República, que desde o início da gestão Lula, e ainda hoje, conta com um ativo assessor especial para as relações internacionais, egresso do Partido dos Trabalhadores.

Não cabe aqui retomarmos a argumentação daqueles que criticam as decisões e o modus operandi daquilo que alguns chamaram de "diplomacia companheira". O fato de Celso Amorim, chanceler do governo Lula, ter se filiado ao Partido dos Trabalhadores, em 2009, certamente foi visto pelos críticos como comprovação da partidarização da política externa (recorde-se que a corporação diplomática do país sempre se aferrou à concepção de política externa como política de Estado). Vale ressaltarmos, porém, que a visibilidade do dissenso intracorporativo se deve não apenas ao não compartilhamento de políticas e estratégias, mas também àquilo que a Análise de Política Externa denomina de "política da burocracia". Cabe recordarmos que vários dos mais importantes cargos do serviço exterior brasileiro foram ocupados, na gestão Lula da Silva, por diplomatas que amargaram certo escanteamento durante o governo anterior. Deve-se destacar, ainda, como discutido anteriormente, que esta perda da coesão 
O Itamaraty e a Política Externa Brasileira: Do Insulamento à Busca de Coordenação...

interna do Itamaraty pode ser vista tanto como fruto da politização da política externa, hoje inevitável, quanto como elemento central neste processo, ainda ambíguo, de desencapsulamento do Ministério das Relações Exteriores.

Como demonstrado neste trabalho, contudo, o Itamaraty tem reagido de distintas maneiras às inúmeras pressões para que seja superado o seu tradicional insulamento, oriundas de variadas fontes. Parece haver evidências, como vimos, de que o MRE tem, no geral, preservado a sua capacidade de coordenação da política externa do país, como também apontado por alguns outros autores. Seja como for, fato é que, para o bem ou para o mal, provavelmente para ambos, a política externa do país cada vez mais se assemelha às políticas públicas características de um Estado democrático, com uma sociedade complexa e plural, crescentemente atrelada aos fluxos internacionais.

\section{Notas}

1. A pesquisa que deu origem a este trabalho contou com o financiamento do $\mathrm{CNPq}$ e da Fapemig, a quem o autor gostaria de agradecer. O autor agradece também a Fernando Santana Felipe e a Luísa Gonçalves de Medeiros, pela competente e dedicada assistência na pesquisa, bem como a Dawisson Belém Lopes, Luiz Feldman e Rogério Farias, pela leitura atenta de uma versão anterior, o que, obviamente, não significa que eles concordam com os argumentos aqui desenvolvidos, nem os faz responsáveis pelos problemas eventualmente remanescentes. Uma versão anterior foi apresentada no II Encontro da Associação Brasileira de Relações Internacionais, realizado na Pontifícia Universidade Católica do Rio de Janeiro, de 22 a 24 de julho de 2009.

2. Fonte: site do MEC. Disponível em: <http://www.e-mec.gov.br>. Acesso em: 18 mai. 2011. [Sites das instituições e correspondência com as coordenações dos cursos.]

3. Fonte: site da CAPES. Disponível em: <http://capes.gov.br/>. Acesso em: 19 mai. 2011. [E sites dos programas de pós-graduação.] 


\section{Carlos Aurélio Pimenta de Faria}

4. Esta é, certamente, a percepção generalizada entre os analistas acadêmicos da política externa brasileira. Contudo, como apontado por Rogério Farias, em comunicação pessoal com o autor, a literatura apresenta escassa comprovação empírica do insulamento criticado.

5. No período militar: Juracy Montenegro Magalhães, ministro das Relações Exteriores de 17 de janeiro de 1966 a 15 de março de 1967; e José de Magalhães Pinto, de 15 de março de 1967 a 30 de outubro de 1969. Na Nova República: Olavo Setúbal; de 15 de março de 1985 a 14 de fevereiro de 1986; Roberto Costa de Abreu Sodré, de 14 de fevereiro de 1986 a 15 de março de 1990; Francisco Rezek, de 15 de março de 1990 a 13 de abril de 1992; Celso Lafer, de 13 de abril de 1992 a 2 de outubro de 1992; Fernando Henrique Cardoso, de 5 de outubro de 1992 a 20 de maio de 1993; e novamente Celso Lafer, de 29 de janeiro de 2001 a $1^{\circ}$ de janeiro de 2003. (Fonte: dados extraídos do site do Ministério das Relações Exteriores).

6. Base do cálculo: abril de 1964 a junho de 2011. Fonte: dados extraídos do site do Ministério das Relações Exteriores. Tabulação própria.

7. Fonte: Lei Orçamentária Anual 2010, "Execução Orçamentária por Função". Disponível em: <http://www8.senado.gov.br/businessobjects/enterprise 115/desktoplaunch/siga/abreSiga.do?docId=3941520\&kind=Webi $>$. Acesso em: 16 mai. 2011.

8. Ver, por exemplo, Alexandre (2006), Diniz e Ribeiro (2008) e Neves (2006).

9. Cabe destacarmos, também, que o adensamento das relações internacionais tem ocasionado a reestruturação dos Ministérios de Relações Exteriores da maior parte dos países, como discutido, por exemplo, por Moses e Knutsen (2001) e Bátora (2008). Vale ressaltarmos, também, que pelo menos desde a década de 1950 iniciativas pontuais de busca de articulação intragovernamental e intersetorial têm sido ensaiadas pelo Itamaraty, como arrolado por Castro (1983).

10. Note-se que levantamento similar, feito por Figueira (2010), chegou a um resultado levemente inferior.

11. Esta subseção é baseada em Nogueira et al. (2009).

12. São os seguintes os dezesseis GTs hoje existentes: (1) Administração Pública; (2) Administração Aduaneira e Tributária; (3) Agricultura; (4) Assentamentos Humanos; (5) Ciência e Tecnologia; (6) Comércio e Investimentos; (7) Cultura; (8) Defesa; (9) Desenvolvimento Social; (10) Educação; (11) Energia; 
O Itamaraty e a Política Externa Brasileira: Do Insulamento à Busca de Coordenação...

(12) Meio Ambiente e Mudança do Clima; (13) Saúde; (14) Sociedade da Informação; (15) Transportes; e (16) Turismo.

13. Algumas dessas iniciativas foram arroladas por Saraiva (2006, p. 431).

14. É importante, aqui, definirmos "diplomacia pública" e explicitarmos a maneira como o conceito é empregado neste trabalho. De acordo com Van Ham (2003, p. 428-429), "o conceito de diplomacia pública tem sido definido de diversas maneiras, e o seu papel e lugar na política internacional variaram ao longo do tempo. No que diz respeito aos seus objetivos, deve-se ressaltar aquele de produzir comunicação direta com outros povos, alterando um governo estrangeiro por intermédio da influência sobre os seus cidadãos, ou simplesmente criando uma imagem favorável para as políticas, ações e sistema político e econômico de seu próprio país". Não obstante, acreditamos ser possível pensarmos a diplomacia pública como também voltada para o plano doméstico, a exemplo da maneira como ela é definida por Naren Chitty (2009), já que a busca de maior legitimidade doméstica das estratégias de inserção internacional de um país também pode ser pensada como parte inextricável da política externa.

15. Fonte: compilação própria a partir de informações contidas no site do MRE, coletadas em 16 de maio de 2011. Deve-se considerar que, mesmo se tratando de artigos e entrevistas coletados e reproduzidos no site pelo próprio Itamaraty, omissões são sempre possíveis.

16. Todos os dados e citações desta seção têm como fonte a Newsletter da FUNAG de 18 de junho 2009. Disponível em: <http://www.funag.gov.br/newsletter/newslettertheme/newsletter.2009-06-18.7639762201/view>. Acesso em: 8 jul. 2009.

17. Cabe destacarmos que o Programa de Ação Afirmativa do IRB/MRE é também exemplo das diversas articulações intragovernamentais nas quais está envolvido o Itamaraty, uma vez que o programa é desenvolvido em parceria não apenas com o Ministério da Ciência e Tecnologia, mas também com o Ministério do Desenvolvimento Social e Combate à Fome, a Secretaria Especial dos Direitos Humanos, a Secretaria Especial de Promoção da Igualdade Racial e a Fundação Cultural Palmares.

18. Fonte: Instituto Rio Branco, Editais de admissão à carreira de diplomata dos anos de 2005, 2006, 2007, 2008, 2009, 2010 e 2011. Disponíveis em: $<$ http://www.institutoriobranco.mre.gov.br/pt-br/concurso_de_admissao_a_ carreira_diplomatica.xml>. Acesso em: 16 mai. 2011.

19. Uma análise do impacto das recentes mudanças institucionais no Itamaraty sobre o seu ethos corporativo e seu insulamento, que questiona mais detidamente esta hipótese, pode ser encontrada em Lopes et al. (2010). 
20. Disponível em: <http://www.mre.gov.br/portugues/noticiario/nacional/ selecao_detalhe3.asp?ID_RESENHA=358709>. Acesso em: 14 jul. 2009.

\section{Referências Bibliográficas}

ALEXANDER, Ernest R. Interorganizational coordination: theory and practice. Journal of Planning Literature, v. 7, n. 4, p. 328-343, 1993.

ALEXANDRE, Cristina Vieira Machado. O Congresso brasileiro e a política externa (1985-2005). Dissertação (Mestrado em Relações Internacionais) Pontifícia Universidade Católica do Rio de Janeiro, Rio de Janeiro, 2006.

ALMEIDA, Paulo Roberto de. O estudo das Relações Internacionais do Brasil. São Paulo: Unimarco Editora, 1999.

Do alinhamento recalcitrante à colaboração relutante: o Itamaraty em tempos de AI-5. In: MUNTEAL FILHO, O.; FREIXO, A.; FREITAS, J. V. (Org.). Tempo negro, temperatura sufocante: Estado e sociedade no Brasil do AI-5. Rio de Janeiro: Contraponto, 2008. p. 65-89.

ART, Robert J. A critique of bureaucratic politics. Policy Sciences, v. 4, p. 467-490, 1973.

BARROS, Alexandre de S. C. A formulação e implementação da política externa brasileira: o Itamaraty e os novos atores. In: MUÑOZ, H.; TULCHIN, J. (Ed.). A América Latina e a política mundial. São Paulo: Convívio, 1986. p. $29-42$.

BÁTORA, Joszef. Foreign ministries and the information revolution: going virtual? Boston: Martinus Nijhoff Publishers, 2008.

BECKER, Clara. A diplomacia do pin. Revista Piauí, n. 56, mai. 2011.

BRASIL. Decreto presidencial no. 6.464. Brasília, 27 de maio de 2008.

BRASIL terá adido agrícola em embaixadas. Folha de São Paulo, 15 abr. 2008. Disponível em: <http://www.pecuaria.com.br/info.php?ver=3361>. Acesso em: 14 jul. 2009. 
O Itamaraty e a Política Externa Brasileira: Do Insulamento à Busca de Coordenação...

CASON, Jeffrey; POWER, Timothy. Presidentialization, pluralization, and the rollback of Itamaraty: explaining change in Brazilian Foreign Policy making from Cardoso to Lula. International Political Science Review, v. 30, n. 2, p. 117-140, 2009.

CASTRO, Flávio Mendes de Oliveira. História da organização do Ministério das Relações Exteriores. Brasília: Editora UnB, 1983.

CHEIBUB, Zairo B. Diplomacia e construção institucional: o Itamaraty em uma perspectiva histórica. Dados, v. 28, n. 1, 1985.

A carreira diplomática no Brasil: o processo de burocratização do Itamaraty. Revista de Administração Pública, v. 23, n. 2, p. 97-128, 1989.

CHITTY, Naren. Australian public diplomacy. In: SNOW, N.; TAYLOR, P. (Ed.). Routledge handbook of public diplomacy. Nova Iorque: Routledge, 2009.

CONFEDERAÇÃO NACIONAL DE MUNICÍPIOS. CNM divulga dados inéditos sobre a atuação internacional de municípios. [s.d.]a. Disponível em: http://www.cnm.org.br/institucional/conteudo.asp?iId=116978. Acesso em: 8 jul. 2009.

Conheça a CNM Internacional. [s.d.]b. Disponível em: http://www.cnm.org.br/institucional/interãbra.asp. Acesso em: 8 jul. 2009.

DANESE, Sérgio França. Diplomacia presidencial: história e crítica. Rio de Janeiro: Topbooks, 1999.

DINIZ, Simone; RIBEIRO, Cláudio Oliveira. The role of the Brazilian Congress in foreign policy. Brazilian Political Science Review, v. 2, n. 2, p. 10-38, 2008 .

EMBAIXADA BRASILEIRA EM WASHINGTON. Ministério das Relações Exteriores tem canal no site YouTube. [s.d.]. Disponível em: $<$ http://www.brasilemb.org/index.php?option $=$ com_content $\&$ task=view $\&$ id $=455 \&$ Itemid=129>. Acesso em: 9 jul. 2009.

EXPORTADORES querem adido agrícola. Folha de São Paulo, 4 jul. 2004.

FARIA, Carlos Aurélio Pimenta de. Opinião pública e política externa: insulamento, politização e reforma na produção da política exterior do Brasil. Revista Brasileira de Política Internacional, v. 51, n. 2, p. 80-97, 2008. 
FARIAS, Rogério de Souza. O Brasil e o GATT (1973-1993). Unidades decisórias e política externa. Curitiba: Editora Juruá, 2009.

FIGUEIRA, Ariane C. R. Rupturas e continuidades no padrão organizacional e decisório do Ministério das Relações Exteriores. Revista Brasileira de Política Internacional, v. 53, n. 2, p. 5-22, 2010.

FRANÇA, Cássio; SANCHEZ, Michelle Ratton. A horizontalização da política externa brasileira. Valor Econômico, 24 abr. 2009. Disponível em: <http://www.google.com/notebook/public/03904464067865211657/BDQtiSwoQ4J3vvY0k>. Acesso em: 22 jun. 2009.

LIMA, Maria Regina Soares. Instituições democráticas e política exterior. Contexto Internacional, v. 22, n. 2, p. 265-304, 2000.

Tradição e inovação na política externa brasileira. Plataforma Democrática, Working Paper n. 3, jul. 2010. Disponível em: <http://www.plataformademocratica.org/Arquivos/Tradicao\%20e\%20Inovacao\%20na\%20Politica\%20Externa\%20Brasileira.pdf>. Acesso em: 13 mai. 2011.

LOPES, Dawisson E. B. Da razão de Estado ao republicanismo mitigado. A plausibilidade de uma política externa democraticamente orientada no Brasil contemporâneo. Tese (Doutorado em Ciência Política) - Universidade do Estado do Rio de Janeiro, Rio de Janeiro, 2010.

; FARIA, Carlos Aurélio P.; CASARÕES, Guilherme. Mudanças institucionais no Itamaraty, ethos corporativo e mitigação do insulamento burocrático do serviço exterior brasileiro. In: Anais do 7º Encontro da Associação Brasileira de Ciência Política (ABCP). Recife, Mar Hotel Recife, 4-7 ago. 2010. Disponível em: <http://cienciapolitica.servicos.ws/abcp2010/arquivos/ 16_7_2010_9_57_35.pdf>. Acesso em: 12 nov. 2010.

LOUREIRO, M. R.; ABRUCIO, F. L. Política e burocracia no presidencialismo brasileiro: o papel do Ministério da Fazenda no primeiro governo FHC. Revista Brasileira de Ciências Sociais, v. 14, n. 41, p. 69-89, 1999.

MOSES, Jonathon W.; KNUTSEN, Torbjorn. Inside out: globalization and the reorganization of foreign affairs ministries. Cooperation and Conflict, v. 36, n. 4, p. 355-380, 2001.

MOURA, Cristina Patriota de. O inglês, o parentesco e o elitismo na Casa de Rio Branco. Cena Internacional, ano 8, n. 1, p. 20-34, 2006. 
O Itamaraty e a Política Externa Brasileira: Do Insulamento à Busca de Coordenação...

. O Instituto Rio Branco e a diplomacia brasileira: um estudo de carreira e socialização. Rio de Janeiro: Editora FGV, 2007.

NEVES, João Augusto de Castro. O Congresso Nacional e a política externa brasileira. In: ALTEMANI, H.; LESSA, A. C. (Org.). Relações internacionais do Brasil: temas e agendas. São Paulo: Editora Saraiva, 2006. p. 365-388.

NOGUEIRA, Joana Laura; FARIA, Carlos Aurélio Pimenta de; LOPES, Dawisson Belém. O Itamaraty e a coordenação intragovernamental para a implementação dos acordos de cooperação do Fórum IBAS. Trabalho apresentado no II Encontro da Associação Brasileira de Relações Internacionais/ ISA. Rio de Janeiro, PUC-Rio, 22-24 jul. 2009.

NUNES, Edson. A gramática política do Brasil. Clientelismo e insulamento burocrático. Rio de Janeiro: Jorge Zahar Editor, 1997.

OLIVEIRA, Amâncio Jorge de; PFEIFER, Alberto. O empresariado e a política exterior do Brasil. In: ALTEMANI, H.; LESSA, A. C. (Org.). Relações internacionais do Brasil: temas e agendas. São Paulo: Ed. Saraiva, 2006. p. 389-428.

PENNA FILHO, Pio. O Itamaraty nos anos de chumbo. O Centro de Informações do Exterior (CIEX) e a repressão no Cone Sul (1966-1979). Revista Brasileira de Política Internacional, v. 52, n. 2, p. 43-62, 2009.

PEREIRA, José Alexandre Lopes. O federalismo na diplomacia brasileira: o interesse do Itamaraty nas ações externas de governos subnacionais. Revista Cena Internacional, v. 6, n. 2, p. 144-159, 2004.

PINHEIRO, Letícia. Autores y actores de la política exterior brasileña. Foreign Affairs Latinoamérica, v. 9, n. 2, p. 14-24, 2009.

; NOGUEIRA, Danielle; MACEDO, Vanessa R. Brazilian foreign policy: a tale of several voices? Trabalho apresentado na BISA Annual Conference, Cambridge, 17-19 dez. 2007.

PUNTIGLIANO, Andrés Rivarola. Going global: an organizational study of Brazilian foreign policy. Revista Brasileira de Política Internacional, v. 51, n. 1, p. 28-52, 2008.

PUTNAM, Robert D. Diplomacy and domestic politics: the logic of two-level games. International Organization, v. 42, n. 3, 1988.

SALOMÓN, Mônica; NUNES, Carmen. A ação externa dos governos subnacionais no Brasil: os casos do Rio Grande do Sul e de Porto Alegre. Um estudo 
comparativo de dois tipos de atores mistos. Contexto Internacional, v. 29, n. 1, p. 99-147, 2007.

SARAIVA, José Flávio Sombra. Federalismo e relações internacionais do Brasil. In: ALTEMANI, H.; LESSA, A. C. (Org.). Relações internacionais do Brasil: temas e agendas. São Paulo: Editora Saraiva, 2006. p. 429-456.

SEQUEIRA, Cláudio Dantas. O serviço secreto do Itamaraty. Correio Braziliense, 22 jul. 2007.

SILVA, Elaini C. G. da; SPÉCIE, Priscila; VITALE, Denise. Atual arranjo institucional da política externa brasileira. IPEA, Texto para Discussão, n. 1.489, 2010.

SOUZA, Celina. Condições institucionais de cooperação na região metropolitana de Salvador. In: CARVALHO, I. M. M.; PEREIRA, G. C. (Org.). Como anda Salvador e sua região metropolitana. Salvador: Edufba, 2006. p. 171-185.

VAN HAM, Peter. War, lies, and videotape: public diplomacy and the USA's war on terrorism. Security Dialogue, v. 34, n. 4, p. 427-444, 2003.

VIGEVANI, Tullo. Problemas para a atividade internacional das unidades subnacionais. Estados e municípios brasileiros. Revista Brasileira de Ciências Sociais, v. 21, n. 62, p. 127-139, 2006.

; MARIANO, Karina L. P. A burocracia na integração regional (e no Mercosul): influência no processo decisório. Contexto Internacional, v. 19, n. 2, p. 267-305, 1997.

Resumo

\section{O Itamaraty e a Política Externa Brasileira: Do Insulamento à Busca de Coordenação dos Atores Governamentais e de Cooperação com os Agentes Societários}

Reconhecendo que são crescentes as pressões no sentido da reversão do paradigma ainda relativamente insulado de produção da política exterior do 
O Itamaraty e a Política Externa Brasileira: Do Insulamento à Busca de Coordenação...

Brasil, bem como a sua ampla repercussão doméstica hoje, este trabalho busca: (a) analisar os fatores, tanto domésticos como internacionais, que, a partir da redemocratização do país e das mudanças sistêmicas provocadas pelo fim da Guerra Fria, têm pressionado o Itamaraty no sentido da superação de seu insulamento; e (b) avaliar os instrumentos que têm sido empregados pelo Ministério das Relações Exteriores para a promoção da coordenação intragovernamental (no interior do Executivo) e intergovernamental (entre o Executivo federal e os governos subnacionais), bem como da cooperação intersetorial (governo federal e atores societários), na produção da política externa do país.

Palavras-chave: Itamaraty - Política Externa Brasileira - Insulamento Articulação Intragovernamental, Intergovernamental e Intersetorial

\section{Abstract}

\section{Itamaraty and Brazilian Foreign Policy: From Isolation to the Search for Coordination Amongst Governmental Actors and Cooperation with Societal Actors}

Acknowledging the increasing pressure to reverse the relatively isolationist paradigm of Brazilian foreign policy making, as well as its current broad domestic repercussion, this article seeks to: (a) analyze the factors, both domestic and international, that, since the return to democracy and the systemic changes caused by the end of the Cold War, have pressured the Brazilian Ministry of External Relations (Itamaraty) to overcome its isolation; and (b) evaluate the instruments that have been used by Itamaraty for the promotion of intra-governmental policy coordination (within the Executive Branch) and intergovernmental (between the federal executive and state governments), as well as inter-sector coordination (federal government and social actors), in the formulation of the country's foreign policy.

Keywords: Brazilian Ministry of External Relations (Itamaraty) Brazilian Foreign Policy - Isolation - Intra-governmental, Intergovernmental and Inter-sector Coordination 